\title{
PSYCHOLOGICAL CAPITAL, SOCIAL SUPPORT, AND CAREER CAPITAL OF INDONESIAN STUDENTS IN TAIWAN
}

\author{
Su Jo Ching ${ }^{1}$, Ibnu Siswanto ${ }^{2}$, and Rina Febriana ${ }^{3}$ \\ ${ }^{1}$ Pusan National University, South Korea, ${ }^{2}$ Universitas Negeri Yogyakarta, Indonesia, \\ ${ }^{3}$ Universitas Negeri Jakarta, Indonesia \\ Email: ibnusiswanto@uny.ac.id
}

\begin{abstract}
International experience helps people to obtain an excellent human capital which significantly plays a crucial role to predict individuals' accomplishment both in academic and career. Therefore, this study purports to explore the psychological capital, social support, and career capital among Indonesian students who study in Taiwan. The participants consist of 120 students who were randomly selected and completed the online questionnaires. The findings of this study revealed that Indonesian students who study in Taiwan achieve an above average on their career capital, social support, and psychological capital. Furthermore, there were high and medium relationships among the three variables. It also demonstrated that students' social support fully mediated the relationship between students' career capital and psychological capital. Based on the research findings, conclusions and practical implications were provided.
\end{abstract}

Keywords: career capital, Indonesia, international students, psychological capital, social support

\section{INTRODUCTION}

Education plays significant roles to anticipate the social and global changes. The vocational education, which is different from the general academic school, is specially developed to train students with employment abilities related to the demands of industries [1] The contemporary industries require employees with high competencies, including hard and soft skills [2], [3]. Hard skills refer to technical competency related to a specific job. While soft skills or employability skills refer to general and nontechnical skills required to perform various tasks [4], [5]. Employability skills positively related to an individual ability for managing current job and anticipating career transitions [6] and finally achieving job satisfaction [7].

Jackson [8] revealed that there are some factors that influence an individual's level of employability such as the degree of study, experiences, relationships with others, and activities beyond formal education. Self- efficacy or people beliefs to perform a specific task also positively predicts one's employability [7]. Hence, the psychological, educational, and social aspects have an essential role in shaping the employability of students. Kim, Kim, \& Lee [9] suggested that individuals' employability might be better understood through the lens of human capital theories. This theory declaims that individual and group who have higher levels of career capital (e.g. knowledge, skills, and experiences) will obtain higher achievements [10].

The previous study also revealed that international experience facilitates students to obtain a good career capital, career adaptability, and enhance their career attractiveness [11]. This experience also increases individuals' teamwork and networking [12], as well as their employability and professional competencies that influence the quality and scope of operations of their future job [13]. Therefore, international experience benefits people to achieve higher human capital for their future career. 
In addition, Tsay \& Paramitaningrum [14] reported that there are 3,233 international students from Indonesia in Taiwan. Those students study for bachelor, master, and doctoral degree in universities across Taiwan. The number of Indonesian students who study in Taiwan might be increased because of the New Southbound policy, or Taiwan government strategies to strengthen its relationships with Asian countries through economics, tourism, and education collaboration. Therefore, it is crucial to explore the effects of the international education experience of students from Indonesia on their knowledge and skills attainment. Do their study abroad influence their career capital? Furthermore, what are the relations between psychological capital, social support, and career capital among Indonesian students in Taiwan?

Capital relates to individuals or group's particularly tangible and intangible assets that can be leveraged to achieve favorable accomplishments [15]. People need to make an investment, in many different types of field (e.g., career, business, financial), if they want to get a return [15]. Therefore, to succeed in their career, people need to invest in factors related to their career capital. Human career capital was defined as an individual's talent, knowledge, and skills based on their education and experiences which are crucial for their current and future life [16]. Other scholars define career capital as the essential resources for an individual to be successful in their career [12], the knowledge, skills, and networking that are developed by individual for their career improvement [17], and a sequence of accumulation of competencies both at before graduation and through work experiences of an individual [18].

Human capital might be constructed through four dimensions, including learning ability, education, training, and work experience [19]. Based on Jokinen, Brewster, and Suutari [20], there were three types of knowing that constructively build individual's career capital: knowing why, knowing how, and knowing whom. Knowing why refers to one's self-talent, values, interests, and motivation toward work [21]. Knowing how is defined as individuals' tacit and explicit knowledge and skills related to a professional occupation [12]. Moreover, knowing whom is personal and professional networking between an individual and an important person in the intended work [17].

Individual's career capitals significantly influence individuals' confidence in their career achievements [22]. It helps people to constructively build their reputation and connection to the envisioned job in the future [22]. It also effectively shows the overall level of a person's competency and capability [23]. Furthermore, this career capital is significantly predicted individual's career success [19], [24].

Social support refers to the quality of interaction among the people within a group and their feeling about being cared for and supports [25]. It is also defined as a connection with other people that able to provide assistance and support [26]. Moreover, there are various types of social support such as support from the people within an organization (e.g., supervisor, coworker, administrative staff), and support from family and friends [27], [28].

Social support is closely connected to individual's psychological state, for instance, new graduate students from nursing department experiencing high levels of job strain resulting from a lack of support from its friends and supervisors [29]. In contrast, a high of social support will provide powers to reduce people's stress [30]. Furthermore, this social support stimulates a person's psychological and personal growth that are useful for facilitating job achievements [31], [32]. It also can be an effective way to improve one's belief to effectively do a task [28]. Hence, it can be said that a lack of social support might lead to individuals' low performance, while high social support will encourage their high accomplishment.

Psychological capital is the mental resources that enable people to react positively 
to problems encountering at work [33]. This positive psychological state is manifested by individuals' self-efficacy, hope, optimism, and resilience [34]. Self-efficacy refers to people's belief on his/her ability and effort to complete the challenging tasks [35]. Hope is one's persevering toward its goals and redirecting it paths when it is necessary [36]. Optimism is defined as an individual's perception toward the positive outcome that might come when they face problems [37]. Also, resilience refers to peoples' ability to "bounce back" from their failures, and even effectively managing it to achieve success [34].

Individuals with high positive psychological capital can deal with jobs burnout and the demanding situations [33]. Employees with high mental capital also have higher engagement, satisfaction, and commitment in their work [38]. In an educational setting, this positive psychological state significantly influences students' learning empowerment and engagement [34]; and creative thinking as well [39]. Practitioners and professionals from various organizations, business, and educational institutions recognize this real mental ability as a powerful factor in their personal and organizational performances development [40].

Individual's psychological capital, career capital, and social support positively predict their academic and career achievements. In a study related to the expatriate international assignment, it revealed that international experiences influence employees' career capital [20]. Therefore, this study purports to identify the international students' career capital along with their psychological capital and social support. It proposes hypotheses that there were positive relationships among the three variables (Figure 1). It also further investigates the measurement model of interaction among the Indonesian students' human and social capital.



Figure 1. Research Conceptual Framework

\section{METHOD}

Samples of this study were selected randomly from the Indonesian students in Taiwan in 2017. The researchers mailed the online questionnaires to students from Indonesia who study in Taiwan. A total of 129 students responded and filled out the surveys. Nine of the filled questionnaires were excluded due to incompleteness. Finally, the total samples were 120 international students from Indonesia (Table 1). It consisted of 63 males and 57 females; 18 bachelor, 73 masters, and 29 doctoral students; and students who live in Taiwan less than one year (43), one to two years (48), and more than two years (29). Most of the students are married (74) and the rest are single (46).

Table 1. Participants of the Study

\begin{tabular}{cll}
\hline \multicolumn{1}{c}{ Categories } & Sub-categories & N $(\%)$ \\
\hline \multirow{2}{*}{ Gender } & Male & $63(53)$ \\
& Female & $57(47)$ \\
Degree & Bachelor & $18(15)$ \\
& Master & $73(61)$ \\
Marital status & PhD & $29(24)$ \\
& Married & $46(38)$ \\
Stay in & Single & $74(62)$ \\
Taiwan & $<1$ year & $43(36)$ \\
& 1 2 years & $48(40)$ \\
& $>2 \sim 3$ years & $29(24)$ \\
\hline
\end{tabular}


The psychological capital instrument was developed by Luthans, Avolio, Avey, \& Norman [41] that consisted of four constructs including hope, resilience, self-efficacy, and optimism. The measure took a five-point Likert scale (strongly disagree to strongly agree) and possessed a Cronbach alpha value of overall psychological capital instrument (.89) and constructs of hope (.76), resilience (.72), selfefficacy (.75), and optimism (.79).

The social support instrument was developed by Ray \& Miller [42] that initially consisted of four constructs including support from supervisor, support from the co-worker, support from administration, and support from family. This study selected three significant constructs of social support which highly related to the research purpose and participants' background including support from supervisor, support from friends, and support from family. The Cronbach alpha value for support from supervisor, support from friends, and support from family were $(.92, .90$, and .92 respectively).

The career capital instrument was developed by [20] that originally consisted of three constructs including knowing-how, knowing-why, and knowing whom career capital. The Cronbach alpha value for knowinghow, knowing-why, and knowing whom career capital was $(.88, .86$, and .83 respectively).

\section{RESULTS AND DISCUSSION}

A Pearson correlation and reliability test were conducted to analyze the instruments' validity and reliability. The results (Table 2) revealed that all the instruments, career capital, psychological capital, and social support, were valid and reliable [43]. It indicated that these instruments were possessed a good accuracy to measure students' psychological capital, social support, and their career capital.
Table 2. Validity and reliability of instruments

\begin{tabular}{lcc}
\hline Variables $(\mathrm{N})$ & Validity & $\begin{array}{c}\text { Reliability } \\
(\alpha)\end{array}$ \\
\hline Psychological & $.461^{* * \sim .843^{* *}}$ & .917 \\
Capital & & .913 \\
Social Support & $.492^{* * \sim .794 * *}$ & $.913 * *$ \\
Career capital & $.683^{* * \sim .888^{* *}}$ & .971 \\
\hline
\end{tabular}

Notes: **: Significant; $\mathrm{p}<0.01$

The descriptive analysis results (table 3 ) showed that international students from Indonesia who currently study in Taiwan possessed an above average on their psychological capital (3.78), social support (4.07), and career capital (4.29). It seems that international experiences possible to influence an individual's cognitive, affective, and social capital.

Table 3. Students' Performances and Correlation among the Three Variables

\begin{tabular}{lccccc}
\hline Variables & M & SD & 1 & 2 & 3 \\
\hline 1. Psy. & 3. & & & & \\
Capital & 78 & .64 & 1 & & \\
2. Social & 4. & & & & \\
Support & 07 & .56 & $.765^{* *}$ & 1 & \\
3. Career & 4. & & & & \\
capital & 29 & .57 & $.400^{* *}$ & $.359^{* *}$ & 1
\end{tabular}

Notes: **: Significant; $\mathrm{p}<0.01$

The correlations among the three variables tests results (table 3) illustrated that there was a strong relationship (.765) between students' psychological capital and social support. Furthermore, there were medium correlations between psychological capital and career capital (.400); and career capital and social support (.359).

There were positive and significant relationships among students' career capital, social support, and their psychological capital. This is aligned with Jones [16] statement that individuals' capital reciprocally affected by their psychological capital. Career capital is a unique individual portfolio based on the 
accumulation of experiences at various stages of life which reflects the value of one's competitiveness in the global market [44]. In this study, students' career capital is high, and it was developed through their international experiences of study abroad. This finding cannot be used to conclude that study in other countries will improve an individual's career capital better than students who study at home country because there is no evidence presented in this study. However, these international educational experiences seem to improve students' cognitive and affective behavior and lead to their psychological capital enhancement [45].

Hence, it is suggested to the Indonesian government to promote this international opportunity to study abroad to develop students' career capital and improve their hopes, resiliencies, self-efficacy, and optimism for future career development.
A structural equation modeling (SEM) technique with AMOS 18.0 was carried out to examine the mediating effect of students' social support on the relationship between students' career capital and psychological capital. The final overall confirmatory factor analysis had reasonable fit statistics $(\mathrm{P})(\mathrm{CMIN} / \mathrm{DF}=1.264)$; Root-Mean-Square Error of Approximation $($ RMSEA $=.032)$; Goodness of Fit Index (GFI= .944); Comparative Fit Index (CFI $=.994)$, and Normed Fit Index (NFI=.952). The CMIN/DF values $1.264 \quad(<3)$ indicate that the measurement model is appropriate to the model fit [46]. The RMSEA value (.032) represents a good fit [46]. Byrne [46] revealed that the RMSEA values lower than .05 represent a good fit. Furthermore, this model also has GFI, CFI, and NFI values over 9 indicated an acceptable fit [47].

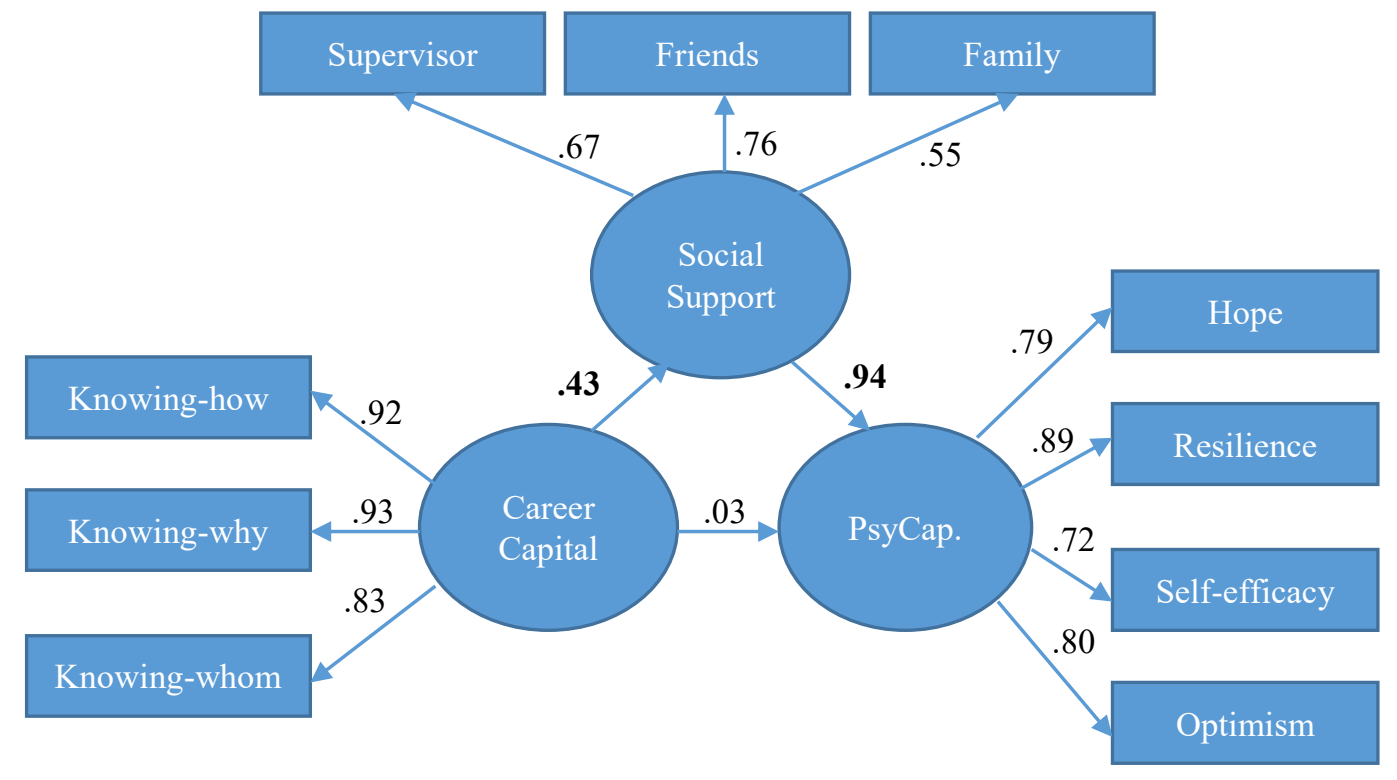

Figure 2. The Mediating Effects of Students' Social Support on the Relationship between Students' Career Capital and Psychological Capital

In addition, knowing-why is the most impressive factor influencing an individual's psychological capital. On the other hand, knowing-whom is the least component which influences students' psychological capital. It indicated that this international experience fostered Indonesian students to recognize better what kind of career they should have in the future. However, they still need to develop their networking with the individuals who are crucial for their job.

Support from friends is the most impressive factor influencing an individual's psychological capital. On the other hand, 
support from students' family is the least component which influences students' mental capital. It seems that students from Indonesia who study in Taiwan perceived their friends who also live in Taiwan as an influential group who give them more support than their family and supervisor.

In addition, the confirmatory factor analyses result revealed that social support fully mediated the relationship between career capital and psychological capital. Students' career capital significantly affects their psychological capital through social support (indirect effects $=$ .43). It indicated that in the realistic environment, students' career capital needs support from supervisor, friends, and their family to be more effectively influence their hope, resilience, self-efficacy, and optimism. This finding aligns with the previous studies which reveal that social supports are important to encourage individuals' psychological state and decrease their work strain [28], [29], [32].

In addition, the highest support for the international students who live far away from their home country come from their friends and followed by the support from supervisors and family. Living abroad is fostering Indonesian students to rely more on their closest person that might be reached. However, the finding on this study cannot be generalized to other international students from other countries or even continents, because of students from Indonesia, like the other students from Asia, mostly build a higher friendship among themselves than their international friends [48]. Furthermore, there are some groups of the student from Indonesia in Taiwan such as Indonesian Students Association (Perhimpunan Pelajar Indonesia), The Indonesian Muslim Student Forum in Taiwan (Forum Mahasiswa Muslim Indonesia di Taiwan), and The Indonesian Student Association in Taiwan (Perhimpunan Pelajar Indonesia di Taiwan) [49]. Those organizations help students starting from their first arrival in Taiwan, then how to adapt to the Taiwanese culture, and finally finish their study. Hence, it is realistic that these activities are providing a supportive environment among the students from Indonesia.

\section{CONCLUSION}

Based on the results of the study, it can be concluded that students from Indonesia who study abroad possessed an above average of career capital, social support, and psychological capital. Furthermore, supports from friends, supervisors, and family are very crucial for their knowledge, skills, and networking development, and finally influence them to have confidence and optimism for their future career. These career capital and psychological capital are significant factors of the employability skills in the industry. Hence, it is suggested to the Indonesian government to promote international education opportunities to students in Indonesia.

\section{REFERENCES}

[1] Z. Arifin, M. Martubi, K. Haryana, M. Solikin, and I. Siswanto, "Penyelarasan Kurikulum Jurusan Pendidikan Teknik Otomotif FT UNYBerbasis Kerangka Kualifikasi Nasional Indonesia," $J$. Pendidik. Teknol. dan Kejuru., vol. 22, no. 1, pp. 119-126, 2014.

[2] A. B. de Guzman and K. O. Choi, "The relations of employability skills to career adaptability among technical school students," J. Vocat. Behav., vol. 82, no. 3, pp. 199-207, Jun. 2013.

[3] P. Handayani, T. Y. Putro, E. Rakhman, and S. J. -Ching, "Learning Outcomes Mapping of the Three Year-Electronic Engineering Diploma in Level-5 Professional Expertise of the National Qualification Framework," J. Pendidik. Teknol. dan Kejuru., vol. 24, no. 1, pp. 102-115, 2018.

[4] S. Ju, D. Zhang, and J. Pacha, "Employability Skills Valued by Employers as Important for Entry-Level Employees With and Without Disabilities," Career Dev. Transit. Except. Individ., vol. 35, no. 1, pp. 29- 
38, May 2012.

[5] N. Wibowo, "Upaya Memperkecil Kesenjangan Kompetensi Lulusan Sekolah Menengah Kejuruan dengan Tuntutan Dunia Industri," J. Pendidik. Teknol. dan Kejuru., vol. 23, no. 1, pp. 45-50, 2016.

[6] F. Kazilan, R. Hamzah, and A. Bakar, "Employability Skills Among the Students of Technical and Vocational Training Centers in Malaysia," Eur. J. Soc. Sci., vol. 35, no. 1, pp. 29-38, 2009.

[7] L. Dacre Pool and P. Qualter, "Emotional Self- Efficacy, Graduate Employability, and Career Satisfaction: Testing the Associations," Aust. J. Psychol., vol. 65, no. 4, pp. 214-223, Dec. 2013.

[8] D. Jackson, "Testing a Model of Undergraduate Competence in Employability Skills and its Implications for Stakeholders," J. Educ. Work, vol. 27, no. 2, pp. 220-242, Mar. 2014.

[9] S. Kim, H. Kim, and J. Lee, "Employee Self-Concepts, Voluntary Learning Behavior, and Perceived Employability," J. Manag. Psychol., vol. 30, no. 3, pp. 264-279, Apr. 2015.

[10] B. C. Martin, J. J. McNally, and M. J. Kay, "Examining the Formation of Human Capital in Entrepreneurship: A Meta-Analysis of Entrepreneurship Education Outcomes," J. Bus. Ventur., vol. 28, no. 2, pp. 211-224, 2013.

[11] R. Huang, "International experience and graduate employability: Perceptions of Chinese international students in the UK," J. Hosp. Leis. Sport Tour. Educ., vol. 13, pp. 87-96, Jul. 2013.

[12] J.-L. Cerdin and C. Brewster, "Talent Management and Expatriation: Bridging Two Streams of Research and Practice," J. World Bus., vol. 49, no. 2, pp. 245252, Apr. 2014.

[13] P. Bryła, "The Impact of International Student Mobility on Subsequent Employment and Professional Career: A Large-scale Survey among Polish Former Erasmus Students," Procedia Soc. Behav. Sci., vol. 176, pp. 633-641, Feb. 2015.

[14] C. L. P. Tsay, "Implications of Indonesian Migration to Taiwan for
Enhancing Bilateral Relations," in In WISC Fifth Global International Studies Conference, 2017.

[15] A. Hargreaves, M. Fullan, J. Pruden, and I. Blackstone Audio, Professional Capital: Transforming Teaching in Every School. Blackstone Audio, Inc, 2012.

[16] J. Pryce-Jones, Happiness at Work: Maximizing Your Psychological Capital for Success. John Wiley \& Sons, 2011.

[17] J.-D. Culié, S. N. Khapova, and M. B. Arthur, "Careers, Clusters and Employment Mobility: The Influences of Psychological Mobility and Organizational Support," J. Vocat. Behav., vol. 84, no. 2, pp. 164-176, Apr. 2014.

[18] J. Felker and M. Gianecchini, "Influence of Pre-Graduation International Experiences on Early Career Internationalization: The Mediation Effect of Career Capital," Eur. Manag. $J$. , vol. 33, no. 1, pp. 60-70, Feb. 2015.

[19] W. Guo, H. Xiao, and X. Yang, "An Empirical Research on the Correlation between Human Capital and Career Success of Knowledge Workers in Enterprise," Phys. Procedia, vol. 25, pp. 715-725, 2012.

[20] T. Jokinen, C. Brewster, and V. Suutari, "Career Capital During International Work Experiences: Contrasting SelfInitiated Expatriate Experiences and Assigned Expatriation," Int. J. Hum. Resour. Manag., vol. 19, no. 6, pp. 979998, Jun. 2008.

[21] K. H. Rosso, B. D., Dekas, "On the Meaning of Work: A Theoretical Integration and Review," Res. Organ. Behav., no. 30, pp. 91-127, 2010.

[22] S. E. Sullivan and M. B. Arthur, "The Evolution of the Boundaryless Career Concept: Examining Physical and Psychological Mobility," J. Vocat. Behav., vol. 69, no. 1, pp. 19-29, Aug. 2006.

[23] M. Dickmann and H. Harris, "Developing career capital for global careers: The role of international assignments," J. World Bus., vol. 40, no. 4, pp. 399-408, Nov. 2005.

[24] T. M. Latzke, M., Mayrhofer, W., Pernkopf-Konhäusner, K., Rohr, C., \& 
Schneidhofer, "Career capital in transitions crossing career fields. Proceeding of EGOS: Bridging continets, cultures and worldviews," in Proceeding of EGOS: Bridging continets, cultures and worldviews, 2013.

[25] M. N. Hajli, "The Role of Social Support on Relationship Quality and Social Commerce," Technol. Forecast. Soc. Change, vol. 87, pp. 17-27, Sep. 2014.

[26] J. Harvey, "Perceived Physical Health, Psychological Distress, and Social Support among Prison Officers," Prison J., vol. 94, no. 2, pp. 242-259, 2014.

[27] A. A. Baiti and S. Munadi, "Pengaruh Pengalaman Praktik, Prestasi Belajar Dasar Kejuruan dan Dukungan Orang Tua terhadap Kesiapan Kerja Siswa SMK," J. Pendidik. Vokasi, vol. 4, no. 2, Jun. 2014.

[28] E. G. Lambert, I. Altheimer, and N. L. Hogan, "Exploring the Relationship Between Social Support and Job Burnout Among Correctional Staff," Crim. Justice Behav., vol. 37, no. 11, pp. 1217-1236, Nov. 2010.

[29] M. Lavoie-Tremblay, L. O'brien-Pallas, C. Gélinas, N. Desforges, and C. Marchionni, "Addressing the Turnover Issue among New Nurses from a Generational Viewpoint," J. Nurs. Manag., vol. 16, no. 6, pp. 724-733, Sep. 2008.

[30] J.-P. Neveu, "Jailed Resources: Conservation of Resources Theory As Applied to Burnout among Prison Guards," J. Organ. Behav., vol. 28, no. 1, pp. 21-42, Jan. 2007.

[31] A. B. Bakker and E. Demerouti, "The Job Demands-Resources Model: State of the Art," J. Manag. Psychol., vol. 22, no. 3, pp. 309-328, Apr. 2007.

[32] S. Mache, K. Vitzthum, B. F. Klapp, and G. Danzer, 'Surgeons' Work Engagement: Influencing Factors and Relations to Job and Life Satisfaction," Surg., vol. 12, no. 4, pp. 181-190, Aug. 2014.

[33] H. K. Spence Laschinger and R. Fida, "New Nurses Burnout and Workplace Wellbeing: The Influence of Authentic Leadership and Psychological Capital,"
Burn. Res., vol. 1, no. 1, pp. 19-28, Jun. 2014.

[34] J. W. You, "The Relationship among College Students' Psychological Capital, Learning Empowerment, and Engagement," Learn. Individ. Differ., vol. 49, no. 49, pp. 17-24, Jul. 2016.

[35] C. Wu, M., Siswanto, I., Ko, "The Influential Factors and Hierarchical Structure of College Students' Creative Capabilities: An Empirical Study in Taiwan," Think. Ski. Creat., no. 26, pp. 176-185, 2017.

[36] J. B. Luthans, B. C., Luthans, K. W., Avey, "Building the Leaders of Tomorrow: The Development of Academic Psychological Capital," $J$. Leadersh. \&mOrganizational Stud., vol. 21, no. 2, pp. 191-199, 2014.

[37] T. J. Thompson, K. R., Lemmon, G.,Walter, "Employee Engagement and Positive Psychological Capital," Organ. Dyn., vol. 44, no. 3, pp. 185-195, 2015.

[38] S. Paek, G. Lee, and T. Kim, "Why Is Hospitality Employees' Psychological Capital Important? The Effects of Psychological Capital on Work Engagement and Employee Morale," Int. J. Hosp. Manag., vol. 50, pp. 9-26, 2015.

[39] M. Wu, I. Siswanto, and T. Mahfud, "No Title," Int. J. Innov. Creat. Chang., vol. 4, no. 2, pp. 90-103, 2018.

[40] F. Luthans, C. M. Youssef, and B. J. Avolio, Psychological Capital and Beyond. USA: Oxford University Press, 2015.

[41] F. Luthans, B. J. Avolio, J. B. Avey, and S. M. Norman, "Positive Psychological Capital: Measurement and Relationship with Performance and Satisfaction," Pers. Psychol., vol. 60, no. 3, pp. 541572, Sep. 2007.

[42] E. B. Ray and K. I. Miller, "Social Support, Home/Work Stress, and Burnout: Who can Help?," J. Appl. Behav. Sci., vol. 30, no. 3, pp. 357-373, Sep. 1994.

[43] R. L. Hair, J. F., Black, W. C., Babin, B. J., Anderson, R. E., \& Tatham, Análise multivariada de dados. 2009.

[44] M. Lamb and M. Sutherland, "The Components of Career Capital for Knowledge Workers in the Global 
Economy," Int. J. Hum. Resour. Manag., vol. 21, no. 3, pp. 295-312, Feb. 2010.

[45] E. Demerouti, E. van Eeuwijk, M. Snelder, and U. Wild, "Assessing the Effects of a 'Personal Effectiveness' Training on Psychological Capital, Assertiveness and Self-awareness using Self-other Agreement," Career Dev. Int., vol. 16, no. 1, pp. 60-81, Feb. 2011.

[46] R. M. Byrne, "Suppressing Valid Inferences with Conditionals," Cognition, vol. 31, no. 1, pp. 61-83, Feb. 1989.
[47] J. S. Tanaka and G. J. Huba, "Employee Engagement and Positive Psychological Capital," Br. J. Math. Stat. Psychol., vol. 38, no. 2, pp. 197-201, Nov. 1985.

[48] C. R. Glass, E. Gómez, and A. Urzua, "Recreation, Intercultural Friendship, and International Students' Adaptation to College by Region of Origin," Int. J. Intercult. Relations, vol. 42, pp. 104117, Sep. 2014.

[49] KDEI-Taipei, "Deklarasi Perhimpunan Pelajar Indonesia (PPI) Taiwan," KDEITaipei, 2010. 